\title{
A CENA: LANÇANDO SOMBRA SOBRE O REAL
}

Vincent Crapanzano

Ce que je vois existe. Seulement, on ne croit en ce que l'on voit que parce qu'on voit ce en quoi on croit.

(J.B. Pontalis, Perdre de vue)

Sentado à minha escrivaninha, vejo uma água-forte chamada Crépuscule, do artista francês contemporâneo Gerard Trignac. É a imagem, rica em sombras, de um enorme castelo cercado por um fosso largo sobre o qual se estende maciça ponte. O ponto de vista é o de quem está sob a ponte, e quem observa o quadro pode sentir o imenso peso daquela construção. Atrás de um dos pilares que a sustentam, vislumbra-se a vela branca de um barco iluminada por um raio de luz. De imediato, a gravura faz pensar em Piranesi, embora seja menos dramática que seus trabalhos, mais arrebatada. Apesar de sugerir castelos e torres sombrias, perigos ocultos e o rio da morte, a própria morte, há algo reconfortante no mistério, na aura que do quadro emana. Ao menos, foi o que encontrei nesses tantos anos em que trabalhei sob sua silenciosa vigilância.

Enquanto olho a água-forte de Trignac, penso em sombras e meiostons - as dimensões ensombreadas da existência social e cultural que nós, antropólogos, costumamos encontrar, de um jeito ou de outro, e que tendemos a afastar de nosso trabalho "sério", como se embaraçados pelo mistério, pelo perigo e pela iminência, a proximidade do que presumimos ser o irracional ou, no mínimo, o efêmero. Evidentemente, outras eras se compraziam com o que Shelley chamava de "mundo do imperscrutável". No primeiro de seus grandes poemas, Alastor ou O Espírito da Solidão, ele se dirige à "mãe deste mundo, da Natureza e da Necessidade". 
I have watched

Thy shadow and the darkness of thy steps, And my heart ever gazes on the depth Of thy deep mysteries. I have made my bed In charnels and on coffins, where black death Keeps record of the trophies won from thee, Hoping to still these obstinate questionings Of thee and thine, by forcing some lone ghost, The messenger, to render up the tale Of what we are (1934: 1l.2-28) ${ }^{1}$.

Quero ressuscitar a dimensão romântica da antropologia, não porque deseje propor uma antropologia romântica, de modo algum, mas porque gostaria de que nos reconciliássemos com nossa herança romântica e o efeito que ela teve sobre nós, mesmo que apenas por sua insistente rejeição ideológica. Com essa rejeição, tal como com a das raízes religiosas judaico-cristãs - de nossa disciplina, que desempenharam um papel tão fundamental no entendimento e na interpretação dos fenômenos que estudamos, freqüentemente perdemos uma dimensão da realidade muito cara àqueles que estudamos (e a nós também, em nossas vidas). Ou, se não a perdemos, se não a ignoramos, suprimimos ou reprimimos, acabamos por reduzi-la de tal maneira a um ou outro paradigma amortecido, que esses mundos de sombras - ou experiências — perdem toda e qualquer realidade empírica que possam ter e toda e qualquer influência que poderiam exercer sobre o comportamento e os pensamentos daqueles que encontramos em nossos trabalhos de campo.

Andei pensando no modo como tendemos a ignorar (por falta de melhor termo) a "subjetivação" dos contextos presumidamente objetivos que buscamos para explicar os fenômenos que observamos. De um modo preliminar, que requereria consideravelmente mais rigor epistemológico do que posso agora oferecer (se é que poderei algum dia), tentei diferenciar a realidade "objetiva" do que chamo de cena ${ }^{2}$. Por "realidade objetiva" quero dizer algo semelhante ao que Alfred Schutz (1970:253 [1979:248249]) denomina "realidade suprema" ou a realidade do senso comum da vida cotidiana que aceitamos sem questionar. Ela inclui, nos termos fenomenológicos de Schutz, "não só objetos, fatos e eventos físicos ao nosso alcance real e potencial, percebidos como tais através do código de percepção simples, mas também referências de apresentação de ordem inferior, pelas quais os objetos físicos da natureza são transformados em objetos socioculturais". É a "província finita do significado que chamamos de 
realidade de nossa vida cotidiana" e, como tal, difere dramaticamente de domínios como "o mundo de imaginações e fantasmas ou o mundo da contemplação científica" ${ }^{3}$.

Quer entendamos a realidade suprema em termos de coercitividade, como William James poderia ter feito, quer como resistência, como os fenomenologistas fariam, ou mesmo em termos de convenções (socialmente construídas e aceitas ou aceitáveis), estaremos supondo uma certa constância partilhada, ou pelo menos negociável, a partir de diferentes perspectivas (Husserl 1931:129-ss.). Trata-se, em resumo, da realidade de referência primária. Em nosso pressuposto empírico comum ou, se assim preferir o leitor, pragmático, a realidade suprema é despida do fantasioso, daquilo que é temporal ou mesmo espacialmente vinculado ao capricho esses deslocamentos de atenção que relacionamos a sentimentos, emoções e humores, identificados com o domínio subjetivo e que não passam de elementos decorativos, epifenômenos, ou como diriam alguns, epifenômenos de epifenômenos. Pois é justamente para esses elementos decorativos, para esses epifenômenos, que quero chamar a atenção, pois eles são, a seu próprio e especial modo, uma dimensão significativa e efetiva do mundo em que vivemos, pensamos e agimos.

Não quero, contudo, reduzir a cena ao subjetivo, pois acredito que isso nos desviaria do que considero ser sua base intersubjetiva. Nesse particular, divirjo da concepção usual da fenomenologia centrada na consciência singular ou na intenção e, mesmo, do senso comum. Devo acrescentar, apesar de não poder aqui prosseguir com minha argumentação, que a subjetividade, a despeito de quanto possa parecer minha, é essencialmente intersubjetiva, tanto em um modo mediado pela linguagem, por exemplo, quanto imediatamente, por meio de encontros reais e imaginados com figuras significativas cercadas de sombras. Para mim, ao menos, a cena é aquela aparência, a forma ou refração da situação "objetiva" em que nos encontramos, colorindo-a ou nuançando-a e, com isso, tornando-a diferente daquilo que sabemos que ela é quando nos damos ao trabalho de sobre ela pensar objetivamente.

Embora colorida e intensamente nuançada, é naquela objetividade que reside a cena. De fato, por mais que a realidade objetiva nos pareça perturbadora em sua objetividade, firmeza e constância, ela nos dá uma segurança epistêmica ou mesmo ontológica. Podemos talvez falar da cena — em analogia com a "dupla voz"* — como "dupla visão". Reconhece- 
mos imediatamente o que consideramos ser a realidade objetiva da situação em que nos encontramos, seja qual for a forma pela qual se encare esta objetividade - como realidade empírica em um sentido cruamente lockiano, por exemplo, ou como o produto de um conjunto de convenções sociais e culturais - e como se dê a nossa experiência direta dessa realidade, em toda a sua excentricidade. Retornarei ao modo como a natureza intersubjetiva de nossa experiência da cena facilita essa "dupla visão". Quero aqui destacar o fato de que é o reconhecimento do objetivo que facilita a precipitação da cena e nossa experiência dela, tanto quanto é a realidade objetiva do psicanalista enquanto psicanalista e a do paciente enquanto paciente que facilitam as projeções da transferência e da contratransferência. Da mesma forma que a identidade projetiva do psicanalista ou a do paciente pode tornar-se tão intensa na transferência e na contratransferência que cada uma ou ambas as partes desse encontro possam vir a perder a referência de suas identidades objetivas, há momentos em que a cena pode substituir a realidade objetiva em que reside ou que, pelo menos, emula.

Ontem, uma de minhas alunas, que está nas últimas etapas de seu trabalho de campo, veio à minha sala. Insegura sobre a possibilidade de ter terminado - "Não fiz todas as entrevistas de que precisava" - e confrontada pelo volume de material desordenado e ainda não assimilado que coletou, estava exausta e confusa. Seus olhos, comumente brilhantes e vivazes, estavam baços e furtivos. Lembro-me de como fiquei chocado na primeira vez em que a vi assim. Foi logo antes de suas provas orais. Como naquela época, ela trouxe ontem para minha sala uma atmosfera sombria tão intensa - escuridão seria uma palavra forte demais - que cheguei a olhar para cima para ver se a luz das lâmpadas havia diminuído. Não havia. Então, alguns minutos mais tarde, depois de falar sobre suas dúvidas, seus olhos acenderam-se subitamente quando ela apresentou um papel em que havia feito anotações confusas sobre suas idéias. Esse movimento foi tão abrupto, tão espontâneo, tão repleto de alívio - como se ela tivesse, de repente, se lembrado do que havia esquecido por tanto tempo - que minha sala se iluminou. Senti que a luz azulada das lâmpadas fluorescentes ganhara um brilho amarelo, como se fosse incandescente. Conseguimos falar sem dificuldade sobre a pesquisa e, enquanto 
conversávamos, minha sala, a iluminação, mesmo seu rosto, seus olhos ganharam leveza... No final de nosso encontro, contei-lhe sobre minha noção de cena e minha reação à ansiedade e ao alívio dela. Ela reconheceu que também havia sentido a mudança no "ambiente da sala". Devo acrescentar que esta aluna tem um espírito independente e não esconde seu ceticismo em relação à minha concepção de antropologia ${ }^{4}$.

Não há, de fato, nada particularmente extraordinário sobre a minha a nossa - experiência. Todos vivenciamos mudanças desse tipo, que associamos pessoalmente a mudanças no humor ou, coletivamente, a mudanças na atmosfera ${ }^{5}$. Elas são freqüentemente descritas em obras literárias. Kate Leslie, a heroína de A Serpente Emplumada, de D. H. Lawrence, lê um dos compridos hinos religiosos de Don Ramón (Don Ramón é, como o leitor recordará, o líder, o profeta em verdade, do movimento nativista mexicano imaginado por Lawrence e que proclama o retorno do deus-sol asteca Quetzalcoatl):

Kate leu aquele comprido folheto diversas vezes, e uma súbita escuridão, como um turbilhão, parecia ter envolvido a manhã. Ela tomou seu café na varanda, e os pesados mamões em suas pilhas pareciam verter como que grandes gotas do brotamento invisível da fonte de vida não-humana. Ela parecia ver esse enorme brotamento e a impulsão do cosmos, progredindo em misteriosa vida. E os homens apenas como pulgões agrupando-se nos brotos tenros, uma aberração ali. Tão monstruosos o desenrolar e a evolução da vida do cosmos, como se até o ferro pudesse crescer qual líquen na profundeza da terra e parar de crescer e começar a perecer. Ferro e pedra entregando a vida, quando chegasse a sua hora d... (Lawrence 1950:256).

Uma mudança no humor escurece a atmosfera em que Kate se encontra. Sua imediata percepção da cena leva, como costuma acontecer, a uma visão que tem talvez tanta realidade quanto a varanda obscurecida, a varanda iluminada pela luz intensa do sol da manhã. Essas mudanças da realidade objetiva da cena para experiências visionárias podem representar um papel importante em nossas vidas criativas ao descortinarem horizontes imaginários - possibilidades que pairam no limite da percepção comum (Crapanzano 2004). Porém, devo acrescentar que elas podem também constranger, mesmo que por negação ou por terror, a realidade suprema. Elas podem chamar a atenção para o artifício, a meu ver, dessa realidade e lançar uma sombra sobre o seu caráter já dado, a sua facticidade. 
While daylight held

The sky, the poet — [Alastor] — kept mute conference

With his still soul. At night the passion came

Like the fierce fiend of a distempered dream,

And shook him from his rest, and led him forth

Into the darkness (Shelley 1934: 11.221-226) .

$\mathrm{Na}$ tormentosa escuridão do sonho assombrado pela idéia da morte, apesar de seu esforço, o poeta não pode dar vida alguma à Natureza "vazia". Ele não pode reunir os dois mundos, o despertado e o sonhado, o real e o ideal.

Deixemos Shelley de lado - posso estar fazendo má leitura de sua obra; é preciso notar que a relação entre a "realidade objetiva" e a cena está, ela própria, sujeita não apenas a diferenças culturais e de época, mas também a gêneros e convenções de cada cultura ou período. Não há dúvida de que há sociedades dispostas a abrirem mão da realidade objetiva em troca da cena, mas falar nestes termos generalizadores de mentalité não apenas envolve o risco de incorrer em estereótipos, mas também de ignorar a sutil economia da relação entre os dois e a dinâmica desse encontro. O poeta romântico - Shelley, Novalis ainda mais - pode ceder à idéia de cena pairando sobre a realidade como um sonho, uma sombra ou uma visão em sua poesia, em sua inspiração, mas deve ter experimentado uma dura realidade que resistia a essa concessão ou que o levou, como aconteceu com De Quincy e Coleridge, entre outros, a encontrar uma fuga em sonhos de ópio ou em algum misticismo. Meu argumento é que o modo como reagimos à cena - cedendo, negando ou ignorando está sujeito ao modo como a situação em que nos encontramos está estruturada [framed] e não, ou pelo menos não tanto, ao caráter ou à disposição. Com controle autoral, Lawrence construiu a reação de Kate ao hino de Don Ramón. De modo menos pessoal, embora igualmente efetivo, se não mais, esse controle - a coreografia da realidade cênica e a pressão de sua suposição - opera no ritual e no teatro.

Olho para o Crépuscule de Trignac e me vem à mente uma cena de minha tenra infância. Tinha quase quatro anos e estava em uma igreja pela primeira vez. Minha mãe, como vim a saber mais tarde, começou a acreditar que os nazistas venceriam a guerra. Embora ela e meu pai fossem 
obstinadamente não-religiosos, ela decidiu que minha irmã e eu deveríamos ser batizados - "para constar" - como ela me disse anos depois, consideravelmente embaraçada. Eu nunca havia estado em uma igreja antes e me sentia aterrorizado com a escuridão, o cheiro rançoso de incenso e, sobretudo, com aquele homem a quem me fizeram chamar de padre e de quem desgostei imediatamente depois que me chamou de "meu filho". Eu queria chorar, mas me contive, ainda mais depois que minha irmã, que tinha menos de um ano, rebentou em lágrimas. Fui o primeiro a ser batizado e não me lembro de nada, além do mau hálito do padre, o gosto de sal, cabelos molhados e murmúrios em uma língua que eu não entendia. Acima de tudo, lembro-me do raio de luz que atingiu meus olhos através de um ou dois caixilhos de vidro transparente de um vitral do qual um homem em uma longa veste branca e dourada e um chapéu cônico como o de um bobo - que eu havia visto em uma revista de quadrinhos - olhava para mim ameaçadoramente. Meus olhos foram ofuscados de tal forma que se encheram de lágrimas, e a expressão daquele homem, quem quer que ele fosse, ficava mudando de forma grotesca.

Por alguma razão, o raio de luz que ilumina a vela do barco no fosso da água-forte de Trignac me lembra aquela luz. Fiquei pensando se ela também ofuscaria os olhos de minha irmã. Ela era bem pequena e estava não nos braços da mãe, mas nos de uma das amigas de meu pai, de quem minha mãe não gostava e que me deu uma pequena cruz dourada em uma corrente para que eu a usasse, como uma menina. Depois minha mãe diria que eu não era obrigado a usá-la. Minha irmã teve sorte, porque se protegeu daquela luz por conta da sombra do padre que se curvou sobre ela. Embora eu não me lembre de ele ter colocado um véu branco sobre meu rosto, lembro-me de que ele cobriu o de minha irmã. Tive que apertar os olhos quando saímos da igreja porque tudo estava claro demais.

Voltarei à dimensão diacrônica — o potencial narrativo — de nossas experiências da cena. Agora quero descrever sua coreografia em um serviço de comunhão que presenciei em uma igreja evangélica conservadora no sul da Califórnia, quando eu pesquisava o fundamentalismo cristão. A igreja era conhecida por seus batismos teatrais, realizados em uma elevada sacada sobre o altar. Aquele serviço de comunhão era um experimento. Mesas, arrumadas para a comunhão, estavam dispostas nas naves por toda a igreja, e aos que comungavam pediam 
que ministrassem a comunhão uns aos outros. No começo, todos hesitaram, mas quando as luzes diminuíram e o órgão começou a tocar música suave e sedutora - não consegui reconhecer o que era - um par atrás do outro foi levado às mesas. Alguns estavam envergonhados, mas a maioria foi envolvida pela ocasião. Eles se olhavam nos olhos, às vezes chorando, nem sempre era possível dizer se de alegria ou de sofrimento, enquanto ministravam a comunhão uns aos outros. Seus olhares transmitiam não apenas o amor que sentiam mutuamente, por Jesus, mas também - eu senti - histórias pessoais que exigiam perdão.

Tanto para mim, a despeito de mim mesmo, quanto para eles, a atmosfera estava repleta de uma sentimentalidade comovente que transformou a igreja em uma cena de tanta intimidade, de tanto amor - como eles certamente diriam - que a própria igreja parecia desvanecer. Ela se tornou um vasto teatro de comunhão, ao mesmo tempo intensamente pessoal e transcendente. Tanto aqueles que ministravam a comunhão como os que simplesmente observavam foram arrebatados. Fiquei pensando se eu era o único, entre os milhares de membros da congregação, que estava distanciado da cena, menos - eu suspeito - por meu olhar "profissional" do que por embaraço voyeurístico. O experimento foi considerado um enorme sucesso, soube mais tarde, e esperava-se que aumentasse o número de fiéis a freqüentar a igreja.

Que o ritual promove um sentido de comunidade ou, como diria Victor Turner (1969:94-165), de communitas, sempre foi do conhecimento comum muito antes do nascimento da antropologia. A efervescência social que Durkheim viu em seu cerne, ou ao menos no cerne dos rituais primitivos, é mais uma projeção da ressecada mente ocidental, eu suspeito, do que um fato objetivo. Não quero negar que haja rituais cujos desfechos são tão frenéticos que há uma perda da consciência individual e uma submersão no grupo, do tipo que acontece em uma discoteca, eu diria. De fato, testemunhei desfechos como esses entre os Hamadsha, os membros de uma irmandade religiosa marroquina conhecida por seus selvagens ritos de exorcismo, quando no meio da noite, de repente, após horas dançando e entoando cânticos em transe, as luzes apagavam-se e, em um rumoroso silêncio - apenas um oxímoro faria justiça àquele momento - 'A'isha Qandisha, o demônio feminino por eles venerado, fazia sua entrada. Embora eu não possa saber o que os participantes realmente sentiram naqueles momentos, todos se lembram de ver 'A'isha em uma manifestação ou outra (os psicólogos, sem dúvida, diriam que quaisquer que tenham sido as experiências individuais dos participantes, elas foram ime- 
diatamente interpretadas no idioma coletivo como uma manifestação do demônio feminino).

Apesar de eu mesmo não ter visto 'A'isha, pude sentir uma presença sombria, que atribuí imediatamente, dado o meu racionalismo (talvez defensivo), à intensa focalização dos participantes do ritual no demônio feminino. Mais tarde, comparei aquela sensação às experiências que todos temos quando, acreditando estar sozinhos, sentimos subitamente a presença de alguém em um cômodo antes de vermos efetivamente a pessoa.

A maior parte dos rituais que presenciei, inclusive muitos atos Hamadsha, ou sobre os quais li, são de fato eventos sem método algum, desprovidos de intensidade dramática. E quando efetivamente acontece esse tipo de dramaticidade, não fica claro se ela produz alguma efervescência. Descrevendo as sessões divinatórias realizadas por curandeiros Azande, Evans-Pritchard (1937) observou que sua dança foi a mais animada apresentação que já havia presenciado e que a música feita pelos curandeiros - uma "conjunção" de gongos e tambores - era inebriante tanto para os que a tocavam quanto para os que a ouviam. "Música, movimentos rítmicos, caretas, vestimentas grotescas, tudo ajudava a criar a atmosfera apropriada para a manifestação de poderes exóticos" (1937:177). Embora o público acompanhasse o espetáculo com interesse, movimentando suas cabeças no ritmo da música e cantando junto com os músicos quando queria, seria um erro, assegura-nos Evans-Pritchard, presumir que a atmosfera era de respeitoso temor. Ao contrário, as pessoas demonstravam jovialidade, conversavam e faziam piadas. Contudo, Evans-Pritchard lembra-nos:

que o público não estava apenas assistindo a uma apresentação de música percussiva, mas também a uma representação ritual de magia. Trata-se de mais do que dança, é uma luta, parte direta e parte simbólica, contra os poderes do mal. O completo significado da sessão como um espetáculo contra a bruxaria pode ser compreendido apenas quando se entende a dança [...] Um curandeiro 'dança as questões' (Evans-Pritchard 1937:178).

O que Evans-Pritchard deixa de explorar é o efeito ritual (dramático ou mesmo psicológico) da disjunção entre a seriedade da sessão - o temor que pode inspirar - e a atitude (às vezes) jovial do público. Não parece haver, no evento, efervescência de grupo ou mesmo foco constante. É possível argumentar que haja desvio persistente? Talvez seja a abstração, tão pessoal em sua impessoalidade quanto coletiva, a atitude ritual mais característica. Um dos erros de muitos estudos sobre rituais é, 
a meu ver, sua derivação da forma e da intenção dramática a partir de um pressuposto desfecho. Como já observei anteriormente (Crapanzano 2004), vários participantes de rituais disseram-me que foi nessas ocasiões que sentiram mais intensamente a solidão.

Com muita freqüência eu - e outros antropólogos — fomos incapazes de distinguir entre um ideal não-realizado e a experiência real na descrição feita pelos participantes de rituais. Lembro-me de tomar parte em um musem Hamadsha, a peregrinação anual, que culmina no encontro dos líderes de duas aldeias rivais: uma delas, Beni Rachid, de status superior à outra, Beni Ouarad ${ }^{7}$. O líder, ou mizwar, de Beni Ouarad, à frente de milhares de seguidores, montado em um garanhão, chega à entrada de Beni Rachid, onde seu mizwar o espera montado em um garanhão branco, cercado de milhares de seus seguidores. O mizwar de Beni Ouarad desmonta e segue a pé através da aldeia o líder de Beni Rachid, que permanece montado, até o santuário do santo Hamadsha que eles veneram. Os dois oram e retornam, então, à entrada da aldeia. Esse é o ideal, o modo como costumava acontecer, mas me disseram que agora os dois líderes se encontram, um deles tendo desmontado, o outro sobre o cavalo, cumprimentam-se e partem. Segundo o que me explicaram, isso se deve ao fato de não poderem seguir o caminho em meio à multidão espremida de adoradores em transe e frenesi. $\mathrm{Na}$ verdade, os dois homens tinham ciúmes das prerrogativas um do outro e acabaram enfrentando-se na justiça em ações fundiárias.

O que pude ver não foi nem o ideal nem a versão "realista". Os dois comandantes encontraram-se no final da aldeia. Não se cumprimentaram. Simplesmente fizeram uma pausa, deram meia-volta e retornaram para suas casas. Quando perguntei aos espectadores o que havia acontecido, eles me asseguraram que não apenas os dois comandantes haviam se saudado, mas também apertado as mãos. Muitos insistiram que o mizwar de Beni Ouarad havia descido do cavalo! Quando insisti com minhas perguntas, eles ficaram tão violentamente irritados que tive que parar. É talvez essa flutuação entre o ideal e o real, a euforia e o senso de insuficiência, que caracterize boa parte da experiência ritual, como argumentei (Crapanzano 1992:260-280) para o caso dos rituais de circuncisão marroquinos e sua eficácia. Um lança uma sombra sobre o outro e vice-versa. O que importa é sua mútua implicação. O ideal não pode ser inteiramente desengajado de sua experiência real, embora eles possam ser, com algum sucesso, diferenciados analiticamente. É por essa razão que eu hesitaria em igualar o ideal à cena. Suas relações com o real têm gramáticas divergentes. 
Muitos estudos sobre rituais, mesmo aqueles que enfatizam a communitas, resistem ao sentido de milagre, de mistério e de estranho que os participantes descrevem, como se, apesar de metafóricos e simbólicos, eles não tivessem nenhum referente real. Embora eu não esteja pessoalmente disposto a aceitar a interpretação do milagre, acredito que temos que perguntar o que está sendo descrito pelo "milagroso", "misterioso" e "sinistro". Antes de atribuirmos a essas interpretações da experiência, ou às suas aproximações nativas, um referencial predeterminado e confortável - ansiedade da castração, digamos, no caso do sinistro; os poderes transcendentais do social, no caso do milagroso ou do misterioso - devemos tentar entender como esses termos e análogos são usados e como eles aparecem no panorama cultural em estudo. O "milagre" sugere na cultura euro-americana uma quebra da cadeia "natural" de eventos que são causalmente unidos tanto de modo mediato quanto imediato. Em verdade, o "milagre" é duplamente milagroso, pois não apenas é milagroso em seus próprios termos, mas também cria milagrosamente uma ruptura em nosso sentido naturalizado de história e torna-se ainda mais extraordinário.

A discussão de Freud (1963) sobre o "sinistro" pode nos servir de modelo, pois embora ele o relacione, em uma de suas manifestações pelo menos, à ansiedade da castração, ele resiste, ou melhor, seu material o força a resistir à postulação de um único referente causal. "Uma experiência sinistra ocorre tanto nas situações em que complexos infantis reprimidos são revividos por alguma impressão, quanto naquelas em que crenças primitivas que superamos parecem mais uma vez confirmadas" (Freud 1963:55). O que é importante em nossa leitura de Freud é o mecanismo que produz o sentido do sinistro: o estranhamente familiar, algo aterrorizante que já é há muito conhecido, mas está esquecido até que ele o seu efeito - seja ativado por uma impressão no presente. Eu destacaria a paradoxal relação entre contingência e repetição: uma repetição que ao mesmo tempo realça e desarma o contingente.

Freud (1963:50) observa, em outro trecho de seu ensaio, que um "efeito sinistro é muitas vezes produzido facilmente pelo apagamento da distinção entre imaginação e realidade, como quando algo que havia sido até então considerado imaginário aparece diante de nós em realidade, ou quando um símbolo assume a função e o significado completos da coisa que ele simboliza e assim por diante". Freud relaciona essa "ênfase da realidade psíquica em comparação com a realidade física" aos sentimentos infantis de onipotência e às práticas mágicas. Sua busca por origens endopsíquicas da experiência reflete, evidentemente, o pressuposto histórico culturalmente específico de seu tempo. Eu preferiria destacar a dimensão interpessoal da 
experiência do sinistro em suas dimensões sincrônica e diacrônica. Em outras palavras, nos termos da situação na qual quem quer que experimente o sinistro se encontre no tempo da experiência e (na medida em que seja evocada de novo) no tempo em que for descrita, e nos termos do passado com-figurado, que insere a si mesmo no presente por meio da lembrança intencional ou não. Uso aqui "com-figurado" para sugerir tanto a articulação do evento passado quanto sua figuração - posso dizer animista? - que proporciona a possibilidade interlocutória.

Olho ansiosamente para a água-forte de Trignac. Observo o modo como os pilares que sustentam a ponte sobre o fosso estão refletidos às avessas nas águas escuras. Seu reflexo, como um triângulo invertido, uma seta, aponta para baixo, para dentro das profundezas misteriosas da água e tudo o que está no fundo. Isso é destacado por uma vela que, por nenhuma razão aparente, se estende da base do pilar. Iluminado pelo mesmo raio de luz que brilha nas velas do que vejo agora ser o barco da morte, seu reflexo escurece à medida que mergulha nas profundezas do fosso. Quaisquer que sejam as associações pessoais que ele evoque afogamento, medo de ser engolido - o pilar e a vela e seus reflexos tornam-se subitamente um mapa bastante ameaçador da realidade psíquica (uma versão dela ao menos), na qual a linha entre o pilar e a realidade da vela e seus reflexos, a linha da contigüidade, que os Sufis chamariam de barzakh, é reduzida a uma faixa escurecida que não pode ser identificada nem com a realidade nem com seu reflexo.

Os Fang do Gabão, que são participantes de um movimento religioso sincrético chamado Bwiti, destacam o papel do assombro ou do miraculoso akyunge - em seus rituais. Embora usualmente traduzido como milagre, akyunge significa, segundo James Fernandez (1982:436), "tudo o que for feito com tão inigualável habilidade e sutileza no sentido de impressionar e estar além da compreensão comum e da imitação".

Entidades sobrenaturais causam estupor por intervirem na ordem natural das coisas e transgredirem o normal. O Bwiti causa espanto em seus membros por 
intervir em suas vidas de tal modo que lhes permite superarem a si mesmos e virem a entender o extraordinário, o oculto, o aspecto relativo à morte de cada coisa. E, assim, estarem em comunicação com ela (Fernandez 1982:436).

Os Bwiti Fang estabeleceram seus padrões de prática ritual com base nos do povo vizinho no Gabão, os Metsoga. Fernandez (1982:438) descreve os "assombros" de um obango - uma dança extática dos Metsogo: "tochas que deslizavam de maneira misteriosa pelo terreno, o crescimento aparente de um broto de bananeira até se tornar uma pequena árvore no decorrer de várias horas, o aparecimento instantâneo de um galo a partir de um ovo e a precipitação de um dançarino na fogueira sem ser queimado". Alguns desses efeitos, no dizer de Fernandez, não passavam de prestidigitação, mas outros eram o resultado de extraordinária habilidade e de planejamento.

\begin{abstract}
Era preciso manipular cuidadosamente cabos para fazer com que as lanternas "flutuassem" pelo terreno. Ou no caso de um estranho som vindo do topo de uma árvore próxima: seria um espírito? Um dançarino se fez voluntário para subir na árvore e descobrir. E ele o fez com uma tocha amarrada ao braço. Mas assim que alcançou o topo, foi derrubado; a tocha e o que parecia ser seu corpo caíram com um grito apavorante através das árvores. No momento seguinte, o mesmo homem pulou para fora da câmara secreta [presumivelmente da capela Bwiti] (Fernandez 1982:438).
\end{abstract}

Espetáculos como esse são apreciados por sua realização artística, mas na medida em que beiram o extraordinário, eles são com facilidade aparentemente tomados por milagres, pelo menos no momento - o ápice — de sua apresentação, ao final de uma cerimônia que se desenrola por toda a noite, o Caminho do Nascimento e da Morte, no qual o ciclo litúrgico-cósmico da crença Bwiti é ensaiado em canção, oração e dança, realçado pelo uso do eboga (um alucinógeno suave). A última parte da cerimônia, o Caminho da Morte, culmina na morte, transformação e ascensão do deus Eyen Zame e na liberação dos ancestrais aprisionados. Esse complexo ritual inclui dois episódios obango altamente dramáticos, separados por períodos menos intensos de canto e dança. Os dois episódios, que têm lugar após a meia-noite e pouco antes do amanhecer, têm o seu apogeu no que os Fang chamam de "um só coração" (nlem mvôre) uma espécie de confluência. Os participantes do ritual, trazendo velas, seguem a harpa sagrada pela floresta em busca dos espíritos de ancestrais perdidos que ainda não encontraram o caminho para a capela, e são 
conduzidos de volta para lá, onde se aglomeram em torno do pilar central e do chefe religioso, tornando-se, no dizer de Fernandez, virtualmente um só ser. "Levantando as velas sobre suas cabeças (idealmente, eles deveriam poder fazer apenas uma chama de todas as velas), eles entoam [...] agora nos tornamos um só coração" (Fernandez 1982:453-454).

Para Fernandez (1982:466-469), os assombros da cerimônia do ritual excitam a imaginação religiosa dos Fang ao confundirem categorias comuns da experiência. "Encontramos nelas [as cerimônias Bwiti dos Fang inspiradas pelas dos Metsogo] uma atmosfera liminar em que os mortos subitamente ganham de novo a vida, animais podem ser homens, brotos subitamente tornam-se árvores maduras, e homens brancos são, de fato, homens negros ou vice-versa. As coisas se confundem, perdem suas categorias - os 'milagres' metsogo tornam as coisas 'assombrosamente ambíguas'". Segundo Fernandez, as confusões semânticas ritualmente induzidas são mais tarde resolvidas, na perspectiva dos Fang, por seus ancestrais, os mortos-vivos. São eles que reclassificam e alinham homens e mulheres segundo seu pertencimento genealógico - no caminho do nascimento e da morte. Embora Fernandez (1982:476-487) relate algumas das visões de iniciados sob a influência do eboga, ele não nos conta como os participantes no Caminho do Nascimento e da Morte descrevem suas experiências durante a cerimônia. Isso fica para a nossa imaginação. Podemos vislumbrar que horas dançando, cantando, ingerindo doses moderadas de um alucinógeno suave, caminhando no meio da noite à luz de velas pela floresta, sempre sombria e cheia de perigos potenciais, encontros (imaginados) com ancestrais mortos possam, todos eles, produzir múltiplas e sempre cambiantes cenas cada vez mais distantes da "realidade suprema."

Indiferente do que se possa dizer sobre o ritual Bwiti, não há dúvida de que ele seja teatral e, como tal, acentue o elemento cênico de tal forma que pareceria ao observador distanciado que a realidade suprema se dissipa. Como isso afeta o panorama Bwiti sobre a vida em geral, sua percepção da vida cotidiana, o reconhecimento do artifício da(s) cena(s), mesmo o da realidade comum, o seu realismo e o modo como configuram e figuram - metaforizam - a cena em e para outras ocasiões, ainda precisa ser determinado. Essas determinações deveriam basear-se não apenas nos relatos experienciais (pois esses sozinhos gerariam talvez uma ênfase exagerada no individualmente subjetivo, em detrimento do intersubjetivo, do interpessoal, do coreografado), mas também e mais formalmente, na maneira como as experiências cênicas são estruturadas e, por conseguinte, estão sujeitas ao regime metapragmático — como a estruturação da cena [framing of the framing], os milagres, governam o modo como a cena é 
articulada, avaliada e configurada; ou como, em outras palavras, a "experiencialidade" da experiência é constituída.

Lanço um olhar nervoso para a fortaleza de Trignac. Ela me lembra agora um cenário de ópera. Penso em calabouços, encarceramentos, as cenas de prisão em A Pequena Dorrit, em O Conde de Monte Cristo, escavação de túneis, fuga, a lentidão da fuga... cair na armadilha de uma realidade ou de outra, as ilusões de liberdade, os constrangimentos do realismo, a libertação imaginativa, as ilusões dessa libertação, maya... Todo o mundo é um sonho. Todo o mundo é um palco. É possível escapar do sonho? Ver além do palco? Por que o faríamos? Um de meus alunos, um ator, observou há alguns dias que, quando se está em cena, não é possível ver o público. Ele não passa de sombras, mas pode-se sentir sua presença, isto é, quando não se está inteiramente arrebatado. E mesmo assim...

Não entrarei na discussão sobre o uso de drogas para produzir uma contra-realidade. Em minha argumentação, qualquer realidade que elas possam produzir fisiologicamente é ainda uma reação imersa na cultura - o produto de um complexo jogo interlocutório. No meu último ano de faculdade em Harvard, para ganhar algum dinheiro, amigos meus participaram de experimentos psicológicos em que lhes era fornecida uma droga - eles não sabiam do que se tratava - e tinham que relatar o que experimentaram. Eles viam luzes, estrelas, "efeitos de luz como a aurora boreal", como disse um deles. Isso era tudo. Eles tinham tomado LSD. O psicólogo era Timothy Leary. Alguns anos mais tarde (se tanto), eles estariam viajando, encontrando seus duplos, banhando-se em êxtase, voando para os céus, descendo aos abismos infernais, experimentando o nirvana, sofrendo os prazeres boschianos do Jardim das Delícias Celestiais, em contato com seus arquétipos. Alguns atravessariam a última fronteira, perderiam seus rumos e nunca voltariam. Para quê? Nunca me esquecerei do dia em que um de meus alunos em Princeton veio à minha sala sob efeito de ácido, desejando, como ele me contou, nunca mais sair daquela viagem. Foi um dia depois dos assassinatos na Kent State University... 
Estou indo longe demais? Quebrando as convenções do meu gênero escolhido, prescrito? Espero ter demonstrado meu argumento. A realidade, a realidade suprema, pode ser dolorosa. Assim disse Freud. Os budistas, os hindus também. Platão entendeu a refinada dor da realidade $-a$ realidade, a das Idéias. Estamos condenados, ele pensava (e seu pensamento infiltrouse, desde então, em nosso pensamento), a um mundo de sombras, refrações de uma realidade que nunca podemos experimentar diretamente, pouco importando quão grande seja o nosso desejo, a nossa disciplina.

Mas por que postulamos uma realidade tão inatingível?

A pergunta é importante, menos por causa de suas implicações idealistas do que pelas empíricas. Por que nós - alguns de nós, ao menos nos agarramos tão obsessivamente ao que chamamos de realidade empírica? Por que essa realidade se tornou o baluarte de uma disciplina epistemológica que, apesar de sua rejeição por qualquer fundamento ético, é conduzida com tamanho rigor moral - isso, moral - um rigor defensivo?

Lembro-me de uma palestra a que assisti, na época de minha pósgraduação, proferida por um antropólogo cuja identidade não revelarei. Ele passou uma hora descrevendo sua metodologia empírica. Havia morado em uma aldeia onde simplesmente anotava de modo minucioso o que as pessoas faziam, mas sem jamais prestar atenção ao que diziam. Acho que nem chegou a aprender a língua deles, por medo de que isso contaminasse sua objetividade e o compromisso com sua metodologia. Extremo, com certeza, absurdo, mas não deixa de ter ressonância em nossos pressupostos empíricos.

Mais uma vez, sinto-me compelido a reiterar que não estou fazendo a defesa do irracional. Ao contrário, peço apenas uma abertura em nosso empirismo para incluir em sua esfera de ação o irracional - o menos que racional. Não há, no caso em estudo, nada irracional, nem mesmo fictício, sobre a cena. Em sua experiência, em sua descrição, em suas interpretações ou não-interpretações, é algo dado.

Sempre relutei em reduzir a cena ao meramente subjetivo por duas razões. A primeira é que, dado o regime empírico que estou contestando, não o empirismo em geral, o subjetivo é freqüentemente reduzido a uma categoria de rejeição. A segunda é que o modo como concebemos o subjetivo é individualizado de maneira a excluir os seus fundamentos interlocutórios, interpessoais. Mesmo quando tentamos nos aprofundar em 
sua estrutura, tendemos a olhar para as causas biográficas (isto é, individualizadas). $\mathrm{Ou}$, sob sua roupagem assim chamada lingüística, para a função formativa da linguagem. Como procurei fazer inicialmente, antes de minha descida retórica ao aparentemente irracional, quero destacar o modo como a cena e mesmo a realidade suprema são construídas. Falamos com excessiva facilidade de construção social da realidade quando deveríamos talvez falar da construção social de cenas e realidade e - o que é ainda mais importante - da construção social do modo como cenas e realidades são relacionadas ou não umas às outras; do modo como elas se hierarquizam - se hierarquia for mesmo a figura apropriada. Outros arranjos são possíveis. Entre eles, incluem-se equações de diferentes cenas e realidades, a rejeição de algumas delas, até sua foraclusão, sua Verwerfung, ou sua obliteração sem deixar sinal. Elas podem estar temporalmente organizadas, digamos, de maneira a oscilarem, em um modo de esconde-esconde ou nos termos da mecânica quântica, entre uma modalidade interpretativa e uma posicional, ou vice-versa.

Concepções construtivistas sociais são sempre um pouco perturbadoras em sua generalidade. Eu gostaria de restringir aqui minha discussão ao modo como as trocas interlocutórias precipitam a cena - e, se não a realidade suprema, sua articulação e avaliação - tanto quanto a relação entre cena e realidade. Como sugeri quando discutia a estruturação e a sua metapragmática da esquematização, a constituição da cena, da realidade e suas relações resultam de um complexo jogo indicial entre interlocutores que, intencionalmente ou não, têm que indexar a si mesmos e a sua relação em um tempo dado. Não há nada particularmente novo sobre essa observação. O que quero destacar, contudo, é que os interlocutores constituindo a si mesmos e aos outros não precisam ser indivíduos com quem alguém se engaje imediata ou mediatamente como, por exemplo, na leitura, mas que eles também podem ser figuras da imaginação ou da memória, beirando o mundo ensombreado do fantasma (em muitas culturas, memória e imaginação são conceitualmente fundidas). Podemos conceber essas duas categorias de interlocutores em termos sincrônicos e diacrônicos ou, se o leitor preferir, em termos de um eixo horizontal e um vertical cuja interseção é o momento experiencial. Dependendo da situação em que alguém se encontra - o modo como é estruturada - os interlocutores imediatos ou mediatos ou os imaginados ou lembrados podem ser dominantes, mas os interlocutores latentes, é minha sugestão, nunca estão inteiramente ausentes ou sem influência na interlocução. Como a focalização nesse ou naquele tipo interlocutório relaciona-se com a constituição e a avaliação da cena e da realidade, é algo a ser determinado caso a caso. 
Processos indiciais nunca são simples atos ostensivos que apontam ou provocam um único elemento em uma realidade constituída - um contexto. Além do argumento bastante óbvio de que, ao se indexar um elemento contextual, também se indexa o contexto em que aquele elemento ocorre, como se fosse, digamos, um contexto em que tal elemento pode ocorrer. Ou eles podem, de maneira irônica, cômica, transgressiva, jogar com a "inadequação" ou com a "surpresa" contextual. Lembro-me de como minha filha, aos três anos de idade, começou a rir quando, sem pensar, pus uma cenoura que eu estava comendo em um copo de vinho vazio para liberar minhas mãos para brincar com o cachorro. Ironia, jogo e transgressão chamam a atenção para a complexidade da dinâmica pragmática e metapragmática, cuja análise está além do escopo deste artigo (ver Crapanzano 2003).

A indexação de todo elemento e, por conseguinte, seu contexto é minimamente uma dupla indexação, pois não apenas ela aponta para o que é - o elemento contextualizante, o contexto - mas também para o que não é. Esse jogo hegeliano com a negação é tão inevitável, ao menos do ponto de vista comunicacional, a ponto de ser sem sentido na maior parte das circunstâncias, isto é, a menos que o próprio negado seja destacado como freqüentemente o é em jogos de palavras. Todavia, seja por negação, seja por afirmação positiva, indicadores podem, como sugeri, apontar simultaneamente para a realidade suprema e uma ou mais cenas "coincidentes". Ao fazê-lo, os indicadores também "definem" a relação entre a cena e a realidade. Ao menos nessas sociedades que privilegiam o realismo, seu realismo, parece possível que esse privilegiar mascare o modo como a indexação dessa realidade também indexa a cena. Quando a cena, porém, é o foco da indexação, parece possível que a indexação da realidade seja mais evidente. É óbvio que essas hipóteses requerem confirmação. O que está claro - e o que tentei demonstrar em minha discussão do ritual - é que há momentos em que a indexação da cena pode mascarar de tal modo a indexação da realidade suprema que aquela realidade se esvai.

Até aqui destaquei o jogo de indexação entre realidade ou realidades e cena ou cenas do ponto de vista de uma única posição discursiva, a do ser falante ou pensante, mas nenhuma posição discursiva, como o destaque na interlocução sugere, é jamais sui generis. É sempre o resultado de complexas dinâmicas interlocutórias que nascem pelo discurso ou pela 
conversação. Elas incluem o jogo da indexação ou, talvez de modo mais acurado, a luta (exceto nas situações mais convencionais) entre interlocutores diferentemente posicionados, incluindo tanto os reais quanto os lembrados e os imaginados. Esse jogo é, como costumo argumentar (Crapanzano 1992), governado por um conjunto de convenções determinantes (ou metapragmáticas) às quais me referi como o Terceiro, ele próprio um foco de luta interlocutória (Crapanzano 1992: introdução, capítulos 3 e 4). Em termos simples, qualquer interlocução sempre envolve uma negociação para definir o modo como a interlocução será esquematizada, quais convenções discursivas prevalecerão e quais procedimentos hermenêuticos e axiológicos serão apropriados para a interpretação e a avaliação. É nesse nível metapragmático - esse estruturar da estrutura [frame] — que o poder, seja no sentido entranhado de Foucault, seja em um outro mais institucionalmente centrado, como no marxismo, insinua-se mais efetiva e cegamente no discurso e sua precipitação da realidade, a cena, e em sua mútua relação ${ }^{8}$. Para que qualquer comunicação seja bem-sucedida, há sempre uma acomodação - uma aceitação da estrutura, convenções e hermenêutica e axiologia relevantes - para a ocasião. É claro que essa aceitação não precisa ser genuína. Ela pode ser prática, política ou simplesmente hipócrita. Apenas o ingênuo aceita a acomodação sem suspeitar. Sempre se esconde atrás de cada interlocução a opacidade - a mente — do outro que lança sua sombra na interlocução .

Há momentos, contudo, em que as partes da interlocução se abandonam nem tanto uma à outra, mas ao mundo intersubjetivo que elas cocriaram. Pelo menos desde o trabalho de Winnicott (1982:104-110) sobre o espaço potencial e a área intermediária da experiência - grosso modo o espaço transicional entre a realidade interior e a exterior - teóricos das relações de objeto na psicanálise têm se preocupado com a dinâmica do espaço-tempo na sessão psicanalítica. Entre os mais importantes está Thomas H. Ogden (1999), que explora o espaço intersubjetivo criado durante a hora psicanalítica, ao qual se refere como um "terceiro analítico intersubjetivo" ou, simplesmente, um "terceiro" ${ }^{10}$. Ogden (1999:462) argumenta que o pensamento psicanalítico contemporâneo "simplesmente não pode mais falar do analista e do analisando como sujeitos separados que tomam um ao outro por objetos". Eles estão submetidos, pelo menos durante a sessão analítica, a um engajamento intersubjetivo (ou dialético) tão forte que o engajamento torna-se (experiencialmente) uma terceira subjetividade que eles têm que considerar tanto de dentro quanto de fora. "O intersubjetivo e o individualmente subjetivo criam, negam e preservam um ao outro" (1999:463). 
Acredito que, no consultório, uma dimensão maior da vida psicológica do analista com o paciente assume a forma de um devaneio concernente aos detalhes cotidianos de sua própria vida... Esses devaneios não são apenas reflexões da falta de atenção, do auto-envolvimento narcísico, de conflitos emocionais não resolvidos e congêneres. Ao contrário, essa atividade psicológica representa formas simbólicas e proto-simbólicas (baseadas em sensação) dadas à experiência não-articulada (e, muitas vezes, ainda não sentida) do analisando enquanto estão tomando forma na intersubjetividade do par analítico (isto é, no terceiro analítico) (Ogden 1999:476).

Ogden (1999:487) destaca a dimensão inconsciente do terceiro intersubjetivo co-criado. Ele enfatiza o modo como o analista subitamente focalizará um objeto comum que ele havia ignorado, por exemplo, o carimbo de mala direta no envelope de uma carta que ele pensava ser confidencial. Ele reconhece que a relação co-criativa é duplamente assimétrica, pois: a) "a exploração do mundo do objeto interno inconsciente e de formas de relação com o mundo externo do analisando" é privilegiada; b) os dois participantes experimentam o terceiro a partir de suas divergentes perspectivas, personalidades, modos de ajuste a seus respectivos mundos, o seu mundo.

Ogden restringe sua discussão à sessão analítica, mas eu argumentaria que somos freqüentemente tão intersubjetivamente cativados que temos que considerar (não há dúvida de que com menos auto-reflexão crítica que o psicanalista) essa ou aquela figuração experiencial da intersubjetividade. Dois exemplos que vêm imediatamente à mente: o primeiro diz respeito àqueles emaranhados de ódio e amargor de longa data, do tipo que Strindberg descreve em "A Dança da Morte"; o segundo refere-se àqueles momentos de encantamento amoroso em que os amantes sentem-se como um só ser, mas têm mesmo assim que se separar. Há ainda toda a sorte de condições patológicas que podem ser entendidas em termos de atração intersubjetiva, a mais óbvia delas sendo a folie à deux, mas teríamos que incluir "perturbações familiares" que atam os membros de uma família uns aos outros de tal modo que eles não podem se libertar ou o fazem precariamente. Todos esses exemplos, bem como os momentos rituais que discuti aqui, são estruturados diferentemente da sessão psicanalítica. As demandas intersubjetivas são passíveis de serem tão intensas que a diferenciação subjetiva pode perder o seu rumo. É certo que ouvi psicanalistas falarem de raros momentos em que perceberam que eles e seus pacientes sentiram-se realmente como um só ser, "como se eles partilhassem uma única consciência". Esses momentos são raros e não cultivados nas sociedades ocidentais, onde são usualmente considerados como ilusórios, mas 
recebem maior crédito em outras sociedades, como vimos no conceito de "um só coração" dos Bwiti, quando os participantes do ritual se aglomeram erguendo suas velas para formarem uma só chama.

Como parte de minha recente pesquisa sobre os Harkis, os argelinos que se aliaram aos franceses durante a Guerra de Independência da Argélia, visitei um dos mais notórios campos em que aqueles que conseguiam escapar do massacre após a independência foram encarcerados ${ }^{11}$.

Mohammed B. crescera em um dos mais notórios desses campos um camp de forestage isolado nas montanhas, perto de Carcassone que ele visita pelo menos uma vez por ano "para se lembrar". Hoje, com exceção dos poucos hippies alemães que acampam ali, a aldeia está abandonada, os casebres de pedra em ruínas e a praça da entrada cheia de carros abandonados e pneus velhos. Apenas a casa do comandante do campo, agora seu chalé de caça, que preside a vista da aldeia, está conservada. Mohammed estava ansioso para me mostrar o campo. Na longa viagem de carro até lá, falamos dos Harkis, de mercenários, da economia francesa, de política e, inevitavelmente, da guerra no Iraque. À medida que nos aproximávamos do campo, Mohammed começou a ficar reflexivo, perdido, imagino, em memórias. Fiquei chocado ao ver quão isolado era o campo. Em vários momentos, ele me pediu para parar e tirar fotos da aldeia e dos arredores e, quando eu o fazia, ele me contava, como se fosse seu dever, sobre um amigo, um pied noir, que ficou tão tocado com as condições desumanas que não conseguiu mais tirar fotos. Fiz o que Mohammed me havia pedido - não gosto particularmente de tirar fotos. Senti-me manipulado. Fiquei indignado e, contudo, cheio de compreensão para com a ambivalência de Mohammed.

Às vezes, com lágrimas nos olhos, ele me mostrava o estábulo onde ele, a mãe e os irmãos moraram, a escola a que foi mandado, o terreno onde brincava, o poço... Fui tomado pelo pensamento de que tudo aquilo que passava por sua mente eu não tinha como saber, mas que eu sabia de algum modo. Na volta, paramos para almoçar. Mohammed bebeu muito vinho, ficou taciturno e, de volta ao carro, cochilou. Foi um sono obliterante, pensei. Quando ele acordou, ficou sentado em silêncio, mexendo de tempos em tempos em seu telefone celular, esperando, imagino, por um telefonema que o tirasse da implosão do mundo de sua memória. Eu também fiquei na esperança de que ele tocasse. Finalmente, após mais ou menos uma hora, Mohammed virou-se para mim e disse que, se não fosse por sua mãe - que sempre insistia em olhar positivamente para o futuro - ele cometeria suicídio. Mas ele não podia desapontá-la (Ela é, de fato, uma mulher notável que conseguiu não apenas sobreviver ao 
horror de ver o marido degolado diante dela e à subseqüente vida no campo, mas também encontrou um emprego que lhe permitiu criar e educar os seus três filhos). Fiquei aturdido pelas palavras de Mohammed, menos em razão do que ele havia dito, mas pelo fato de que eu estava pensando que ele tinha pensamentos suicidas enquanto estava sentado ao meu lado. Não pude dizer coisa alguma. Não havia o que dizer. O carro tornouse uma espécie de prisão. Eu queria fugir. Felizmente, o telefone celular de Mohammed tocou. Era um de seus clientes. Ele é mestre-de-obras.

Todo antropólogo teve experiências como essas. Temos uma relação assimétrica com nossos informantes. Privilegiam-se suas palavras. Ogden poderia dizer que fui tomado por algo como o terceiro intersubjetivo, mas embora eu tenha experimentado uma proximidade cativante, quem sabe até uma fusão com os pensamentos de Mohammed naquele momento, hesito em me referir àquela proximidade, àquela possível fusão como o terceiro. O entendimento de Ogden surge da própria experiência. Ele mesmo fala de estar ao mesmo tempo dentro e fora do terceiro intersubjetivo. Sua teoria reflete - e mistifica inevitavelmente - a experiência. Se assim entender o leitor, é um sintoma da experiência. Ele não pode nem atingir a distância necessária para observá-la de fora, nem pode refletir sobre o jogo da indexação - a luta - que está acontecendo enquanto ele o experimenta sem perturbar, até mesmo destruir, a própria experiência. Há sempre um limite para a nossa consciência autoduplicadora e triplicadora. Dada a construção intersubjetiva da autoconsciência que estou advogando, eu teria que perguntar, em todo caso, como uma consciência putativa da intersubjetividade, sua atratividade, relaciona-se com a subjetividade intersubjetivamente constituída. Não podemos nos deixar seduzir pela interpretação no rumo de uma onisciência pontual.

Olho pela última vez para a fortaleza de Trignac e percebo, de repente, que nunca me perguntei quem lá habita. Há janelas, mas elas estão na penumbra. Não consigo ver nelas mais do que posso ver na mente de outrem. Há alguém olhando para mim? Para alguém que observa o quadro? Minha sala mergulha na escuridão. É o fim de uma tarde de inverno - anoitecer, crépuscule. 
Recebido em 12 de agosto de 2005

Aprovado em 29 de agosto de 2005

Tradução: Rodrigo Maffei Libonati

Vincent Crapanzano é professor no CUNY Graduate Center. E-mail: <vcrapanzano@earthlink.net>

\title{
Notas
}

\author{
${ }^{1}$ Eu observei \\ Tua sombra e a escuridão de teus passos, \\ E meu coração só vê as profundezas \\ De teus mistérios fundos. \\ Eu me deito sobre ossos, ataúdes onde a morte \\ Esconde os troféus que ganhou de ti \\ Na ânsia de calar tenazes perguntas \\ Sobre ti, constrangendo algum espírito \\ Solitário, mensageiro, a dizer \\ Quem somos nós (1934: 11.2-28).
}

${ }^{2}$ Como se verificará, meu uso do termo "cena" não deve ser confundido com a metáfora teatral de Erving Goffman (1959). O estilo próprio de empirismo de Goffman exclui precisamente o que quero dizer por "cena". Nas palestras em que baseei este artigo, com o objetivo de diferenciar minha noção de cena das normalmente usadas pelos sociólogos, usei o termo francês scène, mas no fim das contas isso apenas parecia uma pretensiosa manipulação de palavras. Ressalte-se que o uso do vernáculo acarreta a perda da referência imediata à tradução de Lacan para a expressão freudiana der andere Schauplatz como scène: a cena do sonho.

${ }^{3}$ É importante observar que Schutz reconhece sua dívida para com a noção de "subuniversos" de William James. A realidade suprema de Schutz corresponde grosso modo ao "mundo do sentido" de James. Conferir, deste autor, o ensaio The psychology of belief (s/d.:1028-1030).

${ }^{4}$ Já discuti o conceito de cena com alguns psicanalistas. Embora eles sejam sensíveis enquanto grupo a mudanças de humor e de caráter de seus pacientes e de si mesmos, tiveram uma reação de surpresa quando lhes perguntei sobre mudanças no sentido de realidade imediata durante as sessões de psicanálise. Simplesmente, os seus consultórios eram o contexto. Porém, após pensarem sobre o assunto, começaram a se lembrar de mudanças como estas. Quando os pacientes estavam deprimidos, eles diziam que o consultório parecia mais escuro e menor. Muitos falaram em luz azulada. 
Já em casos de mania, com a euforia do paciente, o consultório iluminava-se e muitos mencionavam a luz amarela. Alguns sentiam que o cômodo ficava mais espaçoso; outros sentiam claustrofobia. Raiva e agressão foram associados com vermelho. Objetos também mudavam. De repente, tornavam-se conscientes de como o estofamento de um sofá estava gasto, ou da poeira na cúpula de um abajur que nunca antes haviam notado. Uma analista disse que um pequeno quadro diante dela, em estilo muito abstrato, que costumava ser para ela uma espécie de ponto de reflexão enquanto escutava seus pacientes, tornava-se maior ou menor dependendo da ocasião. Ela não soube dizer por que nem quando.

${ }^{5}$ Embora não haja dúvida de que o humor e a atmosfera desempenhem um papel importante na descrição, para não falar da constituição da cena, não quero reduzi-la a isso. Ambos são, como observa Charles Altieri (2003:54), englobantes. Humores referemse a experiências interiores; atmosfera, a experiências exteriores. Humores difundem-se e não se ligam, como explica Altieri (2003:54), a objetos específicos: "Nos humores, os afetos parecem estar intimamente relacionados a um estado geral do sujeito. Mas essa relação persiste em não ser algo para o qual se possa estabelecer uma narrativa, talvez porque humores pareçam uma entidade completa, sem começo e sem fim, mas apenas extensão, duração e esvaecimento... Humores são sintéticos e imperialistas, absorvendo detalhes em vez de se conformarem a aparências específicas (2003:54)". Altieri insiste em que, como os humores se difundem, o sujeito intencional não é particularmente importante. "Decerto nos sentimos envolvidos como sujeitos, mas não organizamos as cenas em termos de nossos interesses específicos ou perspectivas enquanto sujeitos. Ao contrário, a subjetividade flutua, variando entre um sentido da própria participação e um sentido de se estar envolvido em estados de espírito que todo sujeito pode alcançar, uma vez que estados de espírito parecem existir independentemente de perspectivas práticas" (2003:54). Eles absorvem a agência para o transpessoal. Embora a atmosfera possa ser diferenciada dos humores em termos de seu foco exterior, eles podem metaforizar um ao outro, como quando minha aluna se referiu à mudança de humor na sala. Tanto humor quanto atmosfera são diferentes do que quero dizer com "cena". Este é um conceito "objetivista", definido em termos de elementos e eventos específicos e que tem grande potencial narrativo e teatral. Não quero, contudo, elaborar essas diferenças, já que as distinções entre humor, atmosfera e cena são inevitavelmente confusas.

${ }^{6}$ Com o céu seguro pela luz do dia

O poeta [Alastor] consultava em silêncio

A alma inerte. À noite, a paixão vinha,

Tal inimigo cruel em sonho aflito

Arrancou-o do descanso e o conduziu

À escuridão (Shelley 1934: 11.221-226).

${ }^{7}$ Para uma descrição mais detalhada dos rituais e das peregrinações Hamadsha, ver Crapanzano 1973, especialmente pp.115-118.

${ }^{8}$ Não pretendo sugerir que não haja nenhuma realidade "dura" lá fora mas, ao contrário, que a realidade, aquilo a que os fenomenólogos se referem como resistência, é originada e recebe forma articulada e valor — desencadeados — pelo discurso. 
${ }^{9}$ Veja minha discussão sobre diálogos de sombras, aqueles diálogos interiores que cada participante dialógico tem silenciosamente consigo mesmo enquanto a troca dialógica com o outro, com outros, transcorre (Crapanzano 1992:213-ss.).

${ }^{10}$ Ogden (1999:464) toma o cuidado de diferenciar sua noção do terceiro do "nome do pai" (nom du père) de Lacan, que Ogden entende como um "meio-termo" entre símbolo e simbolizado, entre o si mesmo e as circunstâncias em que ele se encontra, criando um "espaço em que o sujeito interpretante, auto-reflexivo e simbolizante é gerado". Eu acrescentaria que o terceiro de Ogden tampouco é equivalente ao meu uso do termo como metapragmaticamente autorizado. Embora próximo ao nome do pai de Lacan, o Terceiro, como eu o uso, está em outro nível de abstração, que pode ser simbolizado pelo "nome do pai" como também pode sê-lo pela "Lei", ou encarnado pelo pai ou, nesse sentido, uma figura totêmica ou deus. Quero evitar a implicação psicogenética do termo lacaniano.

${ }^{11}$ Dos aproximadamente 250 mil Harkis, entre 100 e 150 mil foram mutilados e assassinados pela população argelina, em geral no tempo da independência. Apesar da tentativa de De Gaulle para evitar a fuga dos Harkis para a França, por volta de 20 mil famílias conseguiram fazê-lo e foram imediatamente colocadas em campos, alguns por períodos que chegaram a 16 anos. 


\section{Referências bibliográficas}

ALTIERI, Charles. 2003. The rapture: the aesthetics of the affects. Ithaca, NY: Cornell University Press.

CRAPANZANO, Vincent. 1973. The Hamadsha: a study in moroccan ethnopsychiatry. Berkeley: University of California Press.

1992. Hermes' dilemma and

Hamlet's desire: on the epistemology of interpretation. Cambridge: Harvard University Press.

. 2003. "Afterward". In: M. Lambek e P. Antze (eds.), Illness and irony: on the ambiguity of suffering in culture. New York: Berghahn Books. pp. 135148.

2004. Imaginative horizons: an essay in literary-philosophical anthropology. Chicago: University of Chicago Press.

EVANS-PRITCHARD, Edward. 1937. Witchcraft, oracles, and magic among the Azande. Oxford: Clarendon Press.

FERNANDEZ, James. 1982. Bwiti: an ethnography of the religious imagination in Africa. Princeton: Princeton University Press.

FREUD, Sigmund. 1963 [1919]. "The 'uncanny'". In: P. Rieff (ed.), Studies in parapsychology. New York: Collier Books. pp. 19-66.

GOFFMAN, Erving. 1959. The presentation of the self in everyday life. New City, NY: Doubleday Anchor.

HUSSERL, Edmund. 1931. Ideas: a general introduction to pure phenomenology. London: George Allen and Unwin.

JAMES, William. s.d. [1875]. "The psychology of belief". In: Writings: 1878-1899. New York: Library of America. pp. 1021-1056.
LAWRENCE, D. H. 1950. The plumed serpent. Hammondsmith: Penquin.

OGDEN, Thomas H. 1999. "The analytic third: working with intersubjective clinical facts" In: S. A. Mitchell e L. Aron (eds.), Relational psychoanalysis: the emergence of a tradition. Hillsdale, NJ: The Analytic Press. pp. 459-492.

TURNER, Victor. 1969. The ritual process: structure and anti-structure. Chicago: Aldine.

SCHUTZ, Alfred. 1970. On the phenomenology and social relations, editado por Helmut Wagner. Chicago: University of Chicago Press. Tradução para o português: Fenomenologia e relações sociais. 1979. Rio de Janeiro: Zahar Editores.

SHELLEY, Percy Blythe. 1934. Complete poetical work. London: Oxford University Press.

WINNICOTT, D. W. 1982. Playing and reality. New York: Tavistock. 
Resumo

Este artigo explora a relação entre o que se considera como realidade 'objetiva' ou 'suprema' e - digamos — a sua subjetivação: um mundo de sombras, na fronteira da imaginação, que chamo de 'cena'. Sugiro que essas duas 'realidades' são mutuamente implicadas. Argumento que, na medida em que reagimos a (ou criamos) essas cenas que colorem a nossa experiência da realidade objetiva, elas merecem atenção antropológica. Enfatizo a natureza intersubjetiva da própria subjetividade e apresento uma tentativa preliminar de entendimento dos dramas interlocutórios complexos (que ocorrem no ritual, por exemplo, ou na psicanálise) que constituem a cena.

Palavras-chave: Subjetivação, Intersubjetividade, Ritual, Construção da Realidade, Dramas Indiciais

\section{Abstract}

The paper explores the relationship between what we take to be objective or paramount reality and, roughly, its subjectification: a shadowy world, edging on the imaginative, which I call the scene. I suggest that the two "realities" are mutually implicated. I argue that insofar as we respond to (as we create) these scenes that color our experiences of objective reality, they demand anthropological consideration. I stress the intersubjective nature of subjectivity itself and offer a preliminary attempt at understanding the complex interlocutory dramas, occurring in ritual, for example, or psychoanalysis, that constitute the scene. Key words: Subjectification, Intersubjectivity, Ritual, Constructions of Reality, Indexical Dramas 